\section{Evaluation of the effectiveness of transcranial electrostimulation in treatment of neuropsychiatric disorders}

\author{
Gagik Hakobyan ${ }^{1 *}$, Eduard Sekoyan ${ }^{2}$, Karyna Shoman ${ }^{3}$ and \\ Krasnopeeva Ekaterina ${ }^{3}$ \\ ${ }^{1}$ Professor, Head of Department of Oral and Maxillofacial Surgery, Yerevan State Medical \\ University after M. Heratsi, Armenia
}

${ }^{2}$ Professor, Head of Department of Rehabilitology, Physiotherapy and Curortology, Yerevan State Medical University after M. Heratsi, Armenia

${ }^{3}$ Doctor Policlinik N 67, Moscow, Russian Federation

\section{Abstract}

Objectives: Evaluation of the effectiveness the method of transcranial electrostimulation in treatment of neuropsychiatric disorders with the use of a patches by the company "Aganyan".

Materials and methods: The study was a double-blind, randomized, placebo-controlled study, participated 106 patients with neuropsychiatric disorders. All participants in were divided into tables according to gender, age and diagnosis. Each subject was given the "Aganyan" patches and a special brochure, in which the method of application was indicated in detail. The wearable patch includes a flexible substrate, a binder an adhesive layer, with an electrode foil attached to it. Patients applied one patch behind each ear. The patches were applied for eight hours every third day for three months.

To assess the effectiveness of therapy in patients the following tests were used: The Montreal Cognitive Assessment Scale; MMSE Scale: Concise Mental Status Scale; diaries of observation of the patient's condition to identify side effects; special brochures in which the subjects independently indicated the effects of the "Aganyan" patches. Tests were performed before and after the use of the "Aganyan" patches.

Results: When using the patches of the "Aganyan" company, none of the participants in the study had any side effects; According to the results of the Montreal test according to the criterion of memory and the MMSE test, the effectiveness of the patch was noted in patients with all clinical diagnoses. The greatest positive dynamics was revealed according to the results of the Montreal test according to the criterion of memory in patients with migraine (30\%), insomnia $(31 \%)$, vascular dementia (32\%), and according to the results of the MMSE test in patients with diagnoses: cerebrovascular disease: consequences of a cerebral infarction brain $(31 \%)$, vascular dementia (56\%).

Conclusion: The patches of "Aganyan" company have proven its effectiveness through electrical stimulation with low-intensity current in patients in different age groups with different clinical diagnoses.

\section{More Information}

*Address for Correspondence:

Gagik Hakobyan, Professor, Head of Department of Oral and Maxillofacial Surgery, Yerevan State Medical University after M. Heratsi, 0028 Kievyan str. 10 ap. 65 Yerevan, Armenia, Tel: +37491403038;

Email: prom_hg@yahoo.com; hakobyan_gv@rambler.ru

Submitted: August 10, 2021

Approved: August 16, 2021

Published: August 17, 2021

How to cite this article: Hakobyan G, Sekoyan E, Shoman K, Ekaterina K. Evaluation of the effectiveness of transcranial electrostimulation in treatment of neuropsychiatric disorders. J Nov Physiother Rehabil. 2021; 5: 019-026.

DOI: 10.29328/journal.jnpr.1001041

ORCiD: orcid.org/0000-0002-7232-9070

Copyright: @ 2021 Hakobyan G, et al. This is an open access article distributed under the Creative Commons Attribution License, which permits unrestricted use, distribution, and reproduction in any medium, provided the original work is properly cited.

Keywords: Transcranial electrostimulation; Neuropsychiatric disorders; Patches of the "Aganyan" company

A) Check for updates

OPEN ACCESS

\section{Introduction}

Today, among practicing specialists in the treatment of neuropsychiatric disorders, the emphasis is exclusively on drug therapy. But don't forget about simple, affordable, safe methods of positive impact on the human body. One such technique is low-intensity transcranial DC stimulation (tDCS).
Electrical brain stimulation (tDCS) is the effect of a weak direct current on the cerebral cortex through electrodes located on specific areas of the head $[1,2]$.

tDCS is one of the neuromodulation techniques used in neuropsychiatry, also known as microstimulation therapy. Such an effect changes the physiological state of neurons, making them more or, conversely, less prone to excitation [3]. 
Depending on the location of the electrodes, such stimulation leads to a variety of effects, from relieving chronic pain and treating mental illness in patients, to accelerating learning and improving concentration in healthy people.

By activating neurons, tDCS helps to strengthen new connections (synapses) between them [4].

The principle of tDCS is not too complicated. Electrodes applied to the scalp act on the brain with a weak direct current (1-2 milliamperes). A positively charged electrode ("anode") reduces the potential difference on the membrane of neurons, which facilitates their excitation in the event of signals from neighboring neurons. A negatively charged electrode ("cathode"), on the contrary, increases the potential difference, decreasing the excitability of neurons. The result of several minutes of electrical stimulation is an increase in the activity of the cerebral cortex area under the anode, which lasts an hour or more after the completion of the procedure.

In the case of tDCS, for several days in a row, changes occur in interneuronal contacts - synapses in the neurons of the cortex. For example, they can increase in size, making it easier to transmit a signal from one neuron to another. This process is called synaptic plasticity, and it is he who is responsible for the preservation of the effects of tDCS after the completion of the course of exposure [5].

Penetrating through the outer shell of the brain, the current revitalizes certain electrical activities of the brain and suppresses certain activities. Many studies have shown that there are neuropsychological and psychophysiological changes in the areas of the brain that are affected by this method. Studies show tDCS can be a valuable tool for treating neuropsychiatric conditions such as depression, anxiety, insomnia, cognitive deficits, and impaired concentration [6-10].

\section{tDCS has three advantages:}

1. It can be used as an alternative if there are contraindications to drug treatment, such as pregnant women, breastfeeding and those who cannot tolerate the drug.

2. It is an adjunct to medications for the treatment of pain, post-stroke rehabilitation and depression. Enhances the result of medicinal therapy if performed concurrently.

3. It is a short-term and painless treatment, without undesired drug interactions, such as side effects.

To undergo a course of transcranial electrostimulation, special equipment and a daily course in medical institutions are required, few medical institutions are equipped with such devices and not all patients have the opportunity to undergo these sessions every day in clinics.

The development of simple and affordable at-home transcranial electrostimulation techniques that eliminate the use of big equipment and electrical wires or power source is relevant for the treatment of patients with neuropsychiatric disorders.

The research that we carried out was aimed at testing of the effectiveness the method of transcranial electrostimulation in treatment of neuropsychiatric disorders with the use of a patches by the company "Aganyan".

The main difference between the patches made by "Aganyan" and the existing methods of electrical stimulation, is that these patches are not connected to any power source or batteries. This study presents results of using "Aganyan" patches in treatment of neuropsychiatric disorders. The electrodes are made of different metals such as zinc and copper, and not connected to any electrical device such a voltage or current source. The difference in potentials causes electrons to flow on the surface of the skin from one of the electrodes to another. In this sense, one of the electrodes can be considered as a cathode, while another electrode can be considered as an anode. The difference in potentials can be created only when the electrodes are of different metals. These ranges of voltages and electrical currents appear to be very safe for humans with no side effects whatsoever.

\section{Material and methods}

The study was carried out on the basis of the state polyclinic of the patronage service department of the city of Moscow for 90 days. In a double-blind, randomized, placebo-controlled study, participated 106 people. Placebo patches that looked identical to the "Aganyan" patches were used in 30 patients who did not take any medications during the study.

The study conducting 2 different doctors who the patch of Aganyan was applied in the patient's home registered the results of the procedure being carried out, made a statistical analysis and conclusions of the research. In order to avoid subjective interpretation of the results of the study, the doctors conducting the study were also not aware of which of the patients received the placebo and who was the Aganyan patch.

In order to avoid subjective interpretation of the results of the study, the doctors participating in the study were also not aware of which of the patients had received the placebo and who was the Aganyan patch.

The inclusion criteria were:

- patients with confirmed diagnoses (migraine, insomnia, cerebrovascular disease: consequences of cerebral infarction, vascular dementia, depression);

- the age of patients from 50 to 80 years.

Exclusion criteria:

- age up to 18 years; 
- pregnancy and lactation period;

- the presence of an artificial pacemaker (pacemaker);

- oncological diseases;

- acute inflammatory diseases of the scalp and face.

Before enrollment in the study, all participants signed two copies of their informed consent, one of which was handed out to them.

The "Aganyan" Company provided patches, and placebo patches were also prepared that looked identical to the "Aganyan" patches. After enrollment in the study, all participants received a three-month supply of patch. Additional information about the condition of patients with cognitive deficits was obtained from their close relatives. Each subject was warned that in the event of side effects from the patch, he must urgently contact the doctor-investigator. All subjects were advised to stop taking medications that could affect the results of the study (hypnotics, antidepressants, vascular drugs).

After enrollment in the study, all participants received a three-month supply of patch. Additional information about the condition of patients with cognitive deficits was obtained from their close relatives. Each subject was warned that in the event of side effects from the patch, he must urgently contact the doctor-investigator. All subjects were advised to stop taking medications that could affect the results of the study (hypnotics, antidepressants, vascular drugs).

The "Aganyan" Company provided placebo patches were also prepared that looked identical to the "Aganyan" patches that were used in 30 patients who did not take any medications during the study.

All participants in were divided into tables according to gender, age and diagnosis (Tables 1-5).

\begin{tabular}{|c|c|c|c|}
\hline \multicolumn{4}{|c|}{ Table 1: Distribution of participants with a diagnosis of migraine. } \\
\hline age & male & female & total \\
\hline $50-59$ & $2(50 \%)$ & $4(66.6 \%)$ & $6(60 \%)$ \\
\hline $60-69$ & $1(25 \%)$ & $1(16.7 \%)$ & $2(20 \%)$ \\
\hline $70-79$ & $1(25 \%)$ & $1(16.7 \%)$ & $2(20 \%)$ \\
\hline total & $4(100 \%)$ & $6(100 \%)$ & $10(100 \%)$ \\
\hline
\end{tabular}

Table 2: Distribution of participants diagnosed with insomnia.

\begin{tabular}{|c|c|c|c|}
\hline age & male & female & total \\
\hline $50-59$ & $1(14.3 \%)$ & $2(22.2 \%)$ & $3(18.8 \%)$ \\
\hline $60-69$ & $2(28.6 \%)$ & $2(22.2 \%)$ & $4(25 \%)$ \\
\hline $70-79$ & $4(57.1 \%)$ & $5(55.6 \%)$ & $9(56.2 \%)$ \\
\hline total & $7(100 \%)$ & $9(100 \%)$ & $16(100 \%)$ \\
\hline
\end{tabular}

Table 3: Distribution of participants with a diagnosis of cerebrovascular disease: consequences of cerebral infarction.

\begin{tabular}{|c|c|c|c|}
\hline age & male & female & total \\
\hline $50-59$ & $2(15.4 \%)$ & $4(21.1 \%)$ & $6(18.8 \%)$ \\
\hline $60-69$ & $4(30.8 \%)$ & $4(21.1 \%)$ & $8(25 \%)$ \\
\hline $70-79$ & $7(53.8 \%)$ & $11(57.8 \%)$ & $18(56.2 \%)$ \\
\hline total & $13(100 \%)$ & $19(100 \%)$ & $32(100 \%)$ \\
\hline
\end{tabular}

\begin{tabular}{|c|c|c|c|}
\hline \multicolumn{4}{|c|}{ Table 4: Distribution participants diagnosed with vascular dementia. } \\
\hline age & male & female & total \\
\hline $50-59$ & $1(10 \%)$ & $2(13.3 \%)$ & $3(12 \%)$ \\
\hline $60-69$ & $3(30 \%)$ & $4(26.7 \%)$ & $7(28 \%)$ \\
\hline $70-79$ & $6(60 \%)$ & $9(60 \%)$ & $15(60 \%)$ \\
\hline total & $10(100 \%)$ & $15(100 \%)$ & $25(100 \%)$ \\
\hline
\end{tabular}

Table 5: Distribution participants diagnosed with depression.

\begin{tabular}{|c|c|c|c|}
\hline age & male & female & total \\
\hline $50-59$ & $6(24.5 \%)$ & $7(58.3 \%)$ & $13(56.5 \%)$ \\
\hline $60-69$ & $3(27.3 \%)$ & $4(33.3 \%)$ & $7(30.4 \%)$ \\
\hline $70-79$ & $2(48.2 \%)$ & $1(8.4 \%)$ & $3(13.1 \%)$ \\
\hline total & $11(100 \%)$ & $12(100 \%)$ & $23(100 \%)$ \\
\hline
\end{tabular}

Each subject was given "Aganyan" patches and a special brochure, in which the method of application was indicated in detail. The wearable patch includes a flexible substrate, a binder an adhesive layer, with an electrode foil attached to it. Skin moisture is full of minerals, and is accepted as an electrolyte medium. Zinc foil thickness $0.025 \mathrm{~mm}$ Copper foil thickness $0.025 \mathrm{~mm}$. This is a patented (US patent \#10,420,929 B2), first of its kind product for prolonged electrostimulation with optimum effects when used between 3 to 24 hours. The patches are comprised of thin copper and zinc foils that combine to create a galvanic pair that creates direct micro current up to 100 micro-amps and up to 1 volt.

Patients applied one patch behind each ear (Figure 1).

The patches were applied for eight hours every third day for three months. The patch of Aganyan was applied in the patient's home, procedures were performed by family doctors of the state polyclinic of the patronage service.

Patients were warned that if any discomfort (redness, itching of the skin, etc.) occurs, they should immediately stop using the patch and inform the investigators.

To assess the effectiveness of therapy in patients with a therapeutic profile, the following tests were used: The Montreal Cognitive Assessment Scale (Figure 2) [11]; MMSE Scale: Concise Mental Status Scale (Figure 3); diaries of observation of the patient's condition to identify side effects (Table 6); special brochures in which the subjects independently indicated the effects of the patch.

Diaries were distributed to each participant at the beginning of the study, filled out by the patients themselves or their close relatives (in case of cognitive deficit of patients). Tests were performed before and after the use of the patches.

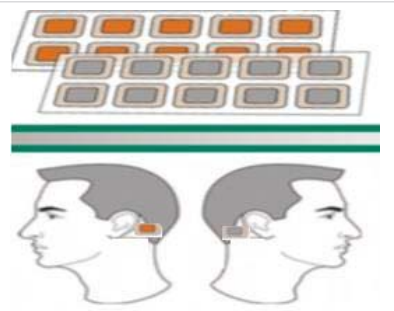

Figure 1: "Aganyan" patches. 


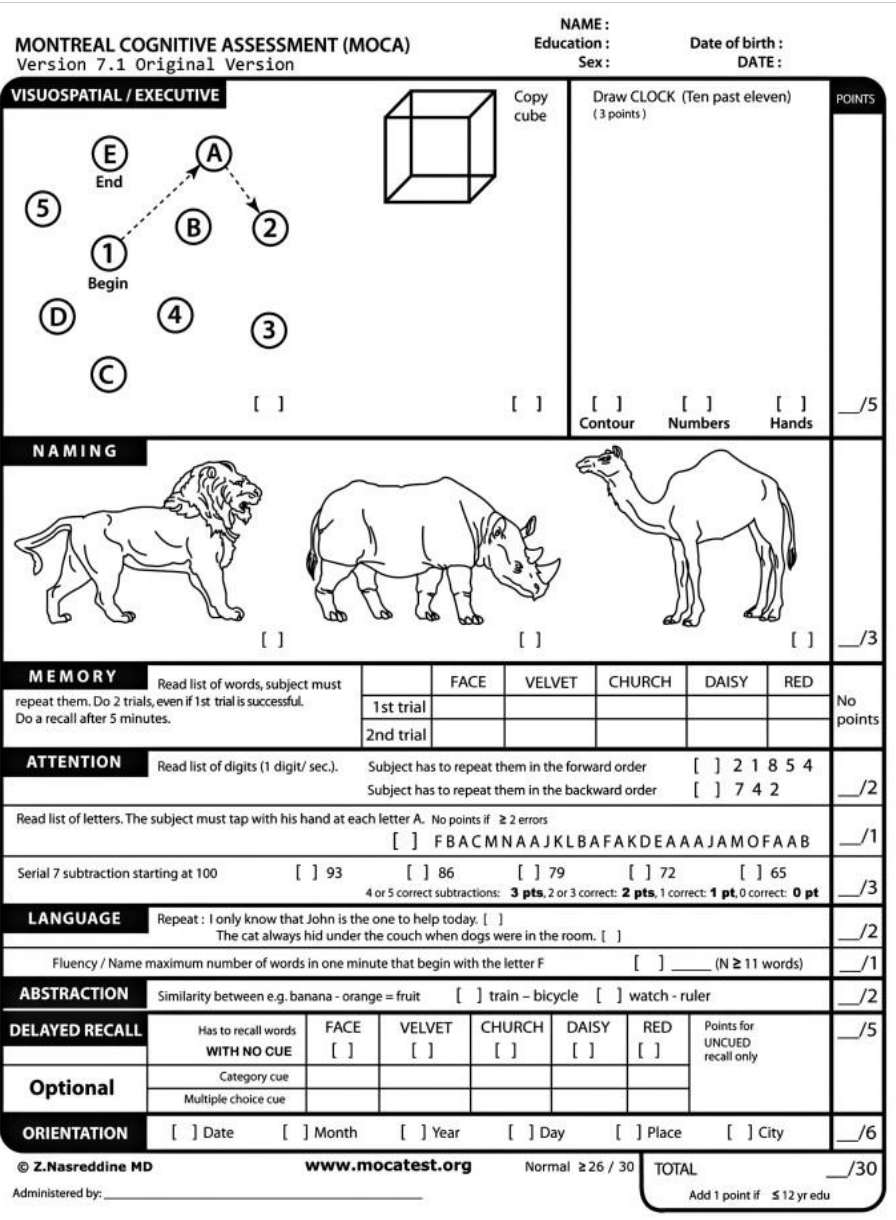

Figure 2: MMSE Scale: Concise Mental Status Scale.

\section{Mini-Mental State Examination (MMSE)}

Patient's Name:

Date:

Instructions: Score one point for each correct response within each question or activity.

\begin{tabular}{|c|c|c|}
\hline $\begin{array}{l}\text { Maximum } \\
\text { Score }\end{array}$ & $\begin{array}{l}\text { Patient's } \\
\text { Score }\end{array}$ & Questions \\
\hline 5 & & "What is the year? Season? Date? Day? Month?" \\
\hline 5 & & "Where are we now? State? County? Town/city? Hospital? Floor?" \\
\hline 3 & & $\begin{array}{l}\text { The examiner names three unrelated objects clearly and slowly, then } \\
\text { the instructor asks the patient to name all three of them. The patient's } \\
\text { response is used for scoring. The examiner repeats them until patient } \\
\text { learns all of them, if possible. }\end{array}$ \\
\hline 5 & & $\begin{array}{l}\text { "I would like you to count backward from } 100 \text { by sevens." ( } 93,86,79, \\
72,65, \ldots) \\
\text { Alternative: "Spell WORLD backwards." (D-L-R-O-W) }\end{array}$ \\
\hline 3 & & $\begin{array}{l}\text { "Earlier I told you the names of three things. Can you tell me what } \\
\text { those were?" }\end{array}$ \\
\hline 2 & & $\begin{array}{l}\text { Show the patient two simple objects, such as a wristwatch and a pencil, } \\
\text { and ask the patient to name them. }\end{array}$ \\
\hline 1 & & "Repeat the phrase: 'No ifs, ands, or buts."' \\
\hline 3 & & $\begin{array}{l}\text { "Take the paper in your right hand, fold it in half, and put it on the floor." } \\
\text { (The examiner gives the patient a piece of blank paper.) }\end{array}$ \\
\hline 1 & & $\begin{array}{l}\text { "Please read this and do what it says." (Written instruction is "Close } \\
\text { your eyes.") }\end{array}$ \\
\hline 1 & & $\begin{array}{l}\text { "Make up and write a sentence about anything." (This sentence must } \\
\text { contain a noun and a verb.) }\end{array}$ \\
\hline 1 & & $\begin{array}{l}\text { "Please copy this picture." (The examiner gives the patient a blank } \\
\text { piece of paper and asks him/her to draw the symbol below. All } 10 \\
\text { angles must be present and two must intersect.) }\end{array}$ \\
\hline 30 & & TOTAL \\
\hline
\end{tabular}

28-30 no cognitive impairment

24-27 objective cognitive impairment

20-23 mild dementia

11-19 mild to moderate dementia

0-10 severe dementia

\section{Results}

After processing the data, we received the following results. When using the patches of the "Aganyan" company, none of the participants in the study had any side effects (Tables 6-16).

According to the results of the Montreal test according to the criterion of memory, the following efficacy results were revealed in patients with clinical diagnoses:

- migraine 30\%;

- insomnia 31\%;

- cerebrovascular disease: consequences of cerebral infarction $22 \%$;

- vascular dementia 32\%;

- depression $13 \%$.

In patients with a diagnosis of migraine, when analyzing brochures and during a personal conversation, a decrease in the number and intensity of headache attacks was noted: out of 4 men - 1 , out of 6 women - 3. In this group of patients, positive dynamics was found in $40 \%$. In patients with a diagnosis of insomnia, when analyzing brochures and in the course of a personal conversation, the duration of sleep increased: out of 7 men in 3, out of 9 women in 6 . In this group of patients, positive dynamics was found in $56 \%$.

In patients diagnosed with depression, after analyzing brochures and in the course of a personal conversation, an improvement in mood and a decrease in anxiety were noted: out of 11 men - 5, out of 12 women - 7. In this group of patients, positive dynamics was found in $52 \%$.

The patches of "Aganyan" company have proven its effectiveness when exposed to the body through electrical stimulation with low-intensity current in patients in different age groups with different clinical diagnoses.

\begin{tabular}{|c|c|c|c|c|c|}
\hline \multicolumn{6}{|c|}{ Diary } \\
\hline \multirow{2}{*}{ Date } & \multirow{2}{*}{ Times of Day } & \multicolumn{2}{|c|}{ Arterial pressure } & \multirow{2}{*}{ Pulse } & \multirow{2}{*}{ Complaints } \\
\hline & & Left hand & Right hand & & \\
\hline & Morning & & & & \\
\hline & Dinner & & & & \\
\hline & Evening & & & & \\
\hline & Morning & & & & \\
\hline & Dinner & & & & \\
\hline & Evening & & & & \\
\hline
\end{tabular}


Table 7: Evaluation of the effectiveness of the "Aganyan" patches according to the results of the Montreal test according to the criterion of memory in patients with a diagnosis of migraine.

\begin{tabular}{|c|c|c|c|c|c|c|c|}
\hline \multirow[t]{2}{*}{ Gender/Age } & \multicolumn{3}{|c|}{ Before applying the patch } & \multicolumn{3}{|c|}{ After applying the patch (after 90 days) } & \multirow[t]{2}{*}{$\begin{array}{l}\text { The number of patients with } \\
\text { positive dynamics (\%) }\end{array}$} \\
\hline & $\begin{array}{l}\text { Named } 5 \text { words } \\
\text { on try } 1\end{array}$ & $\begin{array}{l}\text { Named } 5 \text { words } \\
\text { on try } 2\end{array}$ & Couldn't name & $\begin{array}{l}\text { Named } 5 \text { words } \\
\text { on try } 1\end{array}$ & $\begin{array}{c}\text { Named } 5 \text { words } \\
\text { on try } 2\end{array}$ & Couldn't name & \\
\hline $\mathrm{m} / 50-59$ years & 2 & & & 2 & & & 0 \\
\hline$f / 50-59$ years & 3 & 1 & & 4 & & & 1 \\
\hline $\mathrm{m} / 60-69$ years & 1 & & & 1 & & & 0 \\
\hline$f / 60-69$ years & 1 & & & 1 & & & 0 \\
\hline $\mathrm{m} / 70-79$ years & & 1 & & 1 & & & 1 \\
\hline$f / 70-79$ years & & 1 & & 1 & & & 1 \\
\hline total & & & & & & & $3(30 \%)$ \\
\hline
\end{tabular}

Table 8: Evaluation of the effectiveness of the "Aganyan" patches according to the results of the Montreal test according to the criterion of memory in patients with a diagnosis of insomnia.

\begin{tabular}{|c|c|c|c|c|c|c|c|}
\hline \multirow[t]{2}{*}{ Gender/Age } & \multicolumn{3}{|c|}{ Before applying the patch } & \multicolumn{3}{|c|}{ After applying the patch (after 90 days) } & \multirow{2}{*}{$\begin{array}{l}\text { The number of patients } \\
\text { with positive dynamics (\%) }\end{array}$} \\
\hline & $\begin{array}{l}\text { Named } 5 \text { words } \\
\text { on try } 1\end{array}$ & $\begin{array}{l}\text { Named } 5 \text { words } \\
\text { on try } 2\end{array}$ & Couldn't name & $\begin{array}{l}\text { Named } 5 \text { words } \\
\text { on try } 1\end{array}$ & $\begin{array}{l}\text { Named } 5 \text { words } \\
\text { on try } 2\end{array}$ & Couldn't name & \\
\hline $\mathrm{m} / 50-59$ years & 1 & & & 1 & & & 0 \\
\hline$f / 50-59$ years & 1 & 1 & & 2 & & & 1 \\
\hline $\mathrm{m} / 60-69$ years & 2 & & & 2 & & & 0 \\
\hline$f / 60-69$ years & 1 & 1 & & 1 & 1 & & 0 \\
\hline $\mathrm{m} / 70-79$ years & 1 & 3 & & 2 & 2 & & 1 \\
\hline $\mathrm{f} / 70-79$ years & & 4 & 1 & 3 & 1 & 1 & 3 \\
\hline Total & & & & & & & $5(31 \%)$ \\
\hline
\end{tabular}

Table 9: Evaluation of the effectiveness of the "Aganyan" patches according to the results of the Montreal test according to the criterion of memory in patients with a diagnosis of cerebrovascular disease: the consequences of a cerebral infarction.

\begin{tabular}{|c|c|c|c|c|c|c|c|}
\hline \multirow[t]{2}{*}{ Gender/Age } & \multicolumn{3}{|c|}{ Before applying the patch } & \multicolumn{3}{|c|}{ After applying the patch (after 90 days) } & \multirow[t]{2}{*}{$\begin{array}{l}\text { The number of patients with } \\
\text { positive dynamics (\%) }\end{array}$} \\
\hline & $\begin{array}{l}\text { Named } 5 \text { words } \\
\text { on try } 1\end{array}$ & $\begin{array}{l}\text { Named } 5 \text { words } \\
\text { on try } 2\end{array}$ & Couldn't name & $\begin{array}{l}\text { Named } 5 \text { words } \\
\text { on try } 1\end{array}$ & $\begin{array}{l}\text { Named } 5 \text { words } \\
\text { on try } 2\end{array}$ & Couldn't name & \\
\hline $\mathrm{m} / 50-59$ years & 1 & 1 & & 2 & & & 1 \\
\hline f/50-59 years & 2 & 2 & & 4 & & & 2 \\
\hline $\mathrm{m} / 60-69$ years & 1 & 3 & & 2 & 2 & & 1 \\
\hline $\mathrm{m} / 60-69$ years & 2 & 2 & & 3 & 1 & & 1 \\
\hline $\mathrm{m} / 70-79$ years & 1 & 5 & 1 & 2 & 4 & 1 & 1 \\
\hline $\mathrm{m} / 70-79$ years & 2 & 7 & 2 & 3 & 6 & 2 & 1 \\
\hline total & & & & & & & $7(22 \%)$ \\
\hline
\end{tabular}

Table 10: Evaluation of the effectiveness of the "Aganyan" patches according to the results of the Montreal test according to the criterion of memory in patients with a diagnosis of vascular dementia.

\begin{tabular}{|c|c|c|c|c|c|c|c|}
\hline \multirow[t]{2}{*}{ Gender/ Age } & \multicolumn{3}{|c|}{ Before applying the patch } & \multicolumn{3}{|c|}{ After applying the patch (after 90 days) } & \multirow[t]{2}{*}{$\begin{array}{l}\text { The number of patients with } \\
\text { positive dynamics (\%) }\end{array}$} \\
\hline & $\begin{array}{l}\text { Named } 5 \text { words } \\
\text { on try } 1\end{array}$ & $\begin{array}{l}\text { Named } 5 \text { words } \\
\text { on try } 2\end{array}$ & Couldn't name & $\begin{array}{l}\text { Named } 5 \text { words } \\
\text { on try } 1\end{array}$ & $\begin{array}{l}\text { Named } 5 \text { words } \\
\text { on try } 2\end{array}$ & Couldn't name & \\
\hline $\mathrm{m} / 50-59$ years & & 1 & & 1 & & & 1 \\
\hline$f / 50-59$ years & & 2 & & 1 & 1 & & 1 \\
\hline m/60-69 years & 1 & 1 & 1 & 2 & 1 & & 2 \\
\hline f/60-69 лет & & 3 & 1 & 2 & 1 & 1 & 2 \\
\hline $\mathrm{m} / 70-79$ years & & 3 & 3 & 1 & 2 & 3 & 1 \\
\hline f/70-79 years & & 5 & 4 & 1 & 5 & 3 & 1 \\
\hline total & & & & & & & $8(32 \%)$ \\
\hline
\end{tabular}

Table 11: Evaluation of the effectiveness of the "Aganyan" patches according to the results of the Montreal test according to the criterion of memory in patients with a diagnosis of vascular dementia.

\begin{tabular}{|c|c|c|c|c|c|c|c|}
\hline \multirow[t]{2}{*}{ Genderl Age } & \multicolumn{3}{|c|}{ Before applying the patch } & \multicolumn{3}{|c|}{ After applying the patch (after 90 days) } & \multirow[t]{2}{*}{$\begin{array}{l}\text { The number of patients with } \\
\text { positive dynamics (\%) }\end{array}$} \\
\hline & $\begin{array}{l}\text { Named } 5 \text { words } \\
\text { on try } 1\end{array}$ & $\begin{array}{l}\text { Named } 5 \text { words } \\
\text { on try } 2\end{array}$ & Couldn't name & $\begin{array}{l}\text { Named } 5 \text { words } \\
\text { on try } 1\end{array}$ & $\begin{array}{l}\text { Named } 5 \text { words } \\
\text { on try } 2\end{array}$ & Couldn't name & \\
\hline $\mathrm{m} / 50-59$ years & 6 & & & 6 & & & 0 \\
\hline$f / 50-59$ years & 6 & 1 & & 7 & & & 1 \\
\hline m/60-69 years & 3 & & & 3 & & & 0 \\
\hline$f / 60-69$ years & 3 & 1 & & 4 & & & 1 \\
\hline $\mathrm{m} / 70-79$ years & 1 & 1 & & 2 & & & 1 \\
\hline $\mathrm{f} / 70-79$ years & & 1 & & & 1 & & 0 \\
\hline total & & & & & & & $3(13 \%)$ \\
\hline
\end{tabular}


Table 12: Evaluation of the effectiveness of the "Aganyan" patches according to the results of the MMSE test in patients with a diagnosis of migraine

\begin{tabular}{|c|c|c|c|c|c|c|c|}
\hline Gender / Age & $\begin{array}{r}\text { Num } \\
\text { with } \\
\text { before }\end{array}$ & $\begin{array}{l}\text { tients } \\
\text { oints } \\
\text { e patch }\end{array}$ & $\begin{array}{l}\text { Number of patients } \\
\text { with 24-27 points } \\
\text { before / after the patch }\end{array}$ & $\begin{array}{c}\text { Number of patients } \\
\text { with } 20-23 \text { points } \\
\text { before / after the patch }\end{array}$ & \begin{tabular}{|c|} 
Number of patients \\
with 11-19 points \\
before / after the patch
\end{tabular} & \begin{tabular}{|c|} 
Number of patients \\
with $0-10$ points \\
before $/$ after the patch
\end{tabular} & $\begin{array}{l}\text { The number of } \\
\text { patients with positive } \\
\text { dynamics (\%) }\end{array}$ \\
\hline $\mathrm{m} / 50-59$ years & 2 & 2 & & & & & 0 \\
\hline $\mathrm{m} / 50-59$ years & 4 & 4 & & & & & 0 \\
\hline $\mathrm{m} / 60-69$ years & 1 & 1 & & & & & 0 \\
\hline $\mathrm{m} / 60-69$ years & 1 & 1 & & & & & 0 \\
\hline $\mathrm{m} / 70-79$ years & & 1 & 1 & & & & 1 \\
\hline $\mathrm{m} / 70-79$ years & 1 & 1 & & & & & 0 \\
\hline total & & & & & & & $1(10 \%)$ \\
\hline
\end{tabular}

Table 13: Evaluation of the effectiveness of the "Aganyan" patches according to the results of the MMSE test in patients with a diagnosis of insomnia.

\begin{tabular}{|c|c|c|c|c|c|c|c|}
\hline Gender / Age & \multicolumn{2}{|c|}{$\begin{array}{l}\text { Number of patients } \\
\text { with } 28-30 \text { points } \\
\text { before / after the patch }\end{array}$} & $\begin{array}{l}\text { Number of patients } \\
\text { with } 24-27 \text { points } \\
\text { before / after the patch }\end{array}$ & $\begin{array}{l}\text { Number of patients } \\
\text { with } 20-23 \text { points } \\
\text { before / after the patch }\end{array}$ & $\begin{array}{l}\text { Number of patients } \\
\text { with 11-19 points } \\
\text { before / after the patch }\end{array}$ & $\begin{array}{l}\text { Number of patients } \\
\text { with } 0-10 \text { points } \\
\text { before / after the patch }\end{array}$ & \multirow{2}{*}{$\begin{array}{c}\text { The number of } \\
\text { patients with positive } \\
\text { dynamics (\%) }\end{array}$} \\
\hline $\mathrm{m} / 50-59$ years & 1 & 1 & & & & & \\
\hline$f / 50-59$ years & 2 & 2 & & & & & 0 \\
\hline $\mathrm{m} / 60-69$ years & 2 & 2 & & & & & 0 \\
\hline f/60-69 years & 2 & 2 & & & & & 0 \\
\hline $\mathrm{m} / 70-79$ years & 3 & 4 & 1 & & & & 1 \\
\hline f/70-79 years & 3 & 5 & 2 & & & & 2 \\
\hline total & & & & & & & $3(19 \%)$ \\
\hline
\end{tabular}

Table 14: Evaluation of the effectiveness of the "Aganyan" patches according to the results of the MMSE test in patients with a diagnosis of cerebrovascular disease and consequences of cerebral infarction.

\begin{tabular}{|c|c|c|c|c|c|c|c|c|c|}
\hline \multirow{2}{*}{$\begin{array}{l}\text { Gender / Age } \\
\text { m/50-59 years }\end{array}$} & \multicolumn{2}{|c|}{$\begin{array}{c}\text { Number of patients } \\
\text { with } 28-30 \text { points } \\
\text { before / after the patch }\end{array}$} & \multicolumn{2}{|c|}{$\begin{array}{l}\text { Number of patients } \\
\text { with } 24-27 \text { points } \\
\text { before / after the patch }\end{array}$} & \multicolumn{2}{|c|}{$\begin{array}{c}\text { Number of patients } \\
\text { with } 20-23 \text { points } \\
\text { before / after the patch }\end{array}$} & $\begin{array}{c}\text { Number of patients } \\
\text { with } 11-19 \text { points } \\
\text { before / after the patch }\end{array}$ & $\begin{array}{l}\text { Number of patients } \\
\text { with } 0-10 \text { points } \\
\text { before / after the patch }\end{array}$ & \multirow{2}{*}{$\begin{array}{l}\text { The number of } \\
\text { patients with positive } \\
\text { dynamics (\%) } \\
1\end{array}$} \\
\hline & 1 & 2 & 1 & & & & & & \\
\hline$f / 50-59$ years & 1 & 4 & 3 & & & & & & 3 \\
\hline $\mathrm{m} / 60-69$ years & 1 & 3 & 3 & 1 & & & & & 2 \\
\hline f/60-69 years & 2 & 4 & 2 & & & & & & 2 \\
\hline $\mathrm{m} / 70-79$ & & & 5 & 6 & 2 & 1 & & & 1 \\
\hline f/70-79 years & & & 8 & 9 & 3 & 2 & & & 1 \\
\hline total & & & & & & & & & $10(31 \%)$ \\
\hline
\end{tabular}

Table 15: Evaluation of the effectiveness of the "Aganyan" patches according to the results of the MMSE test in patients with a diagnosis of vascular dementia.

\begin{tabular}{|c|c|c|c|c|c|c|c|}
\hline Gender / Age & $\begin{array}{l}\text { Number of patients } \\
\text { with } 28-30 \text { points } \\
\text { before / after the patch }\end{array}$ & $\begin{array}{c}\text { Number of patients } \\
\text { with 24-27 points } \\
\text { before / after the patch }\end{array}$ & $\begin{array}{r}\text { Num } \\
\text { wit } \\
\text { before }\end{array}$ & $\begin{array}{l}\text { itients } \\
\text { oints } \\
\text { e patch }\end{array}$ & $\begin{array}{c}\text { Number of patients } \\
\text { with } 11-19 \text { points } \\
\text { before / after the patch }\end{array}$ & $\begin{array}{c}\text { Number of patients } \\
\text { with } 0-10 \text { points } \\
\text { before / after the patch }\end{array}$ & $\begin{array}{l}\text { The number of } \\
\text { patients with positive } \\
\text { dynamics (\%) }\end{array}$ \\
\hline $\mathrm{m} / 50-59$ years & & 1 & 1 & & & & 1 \\
\hline$f / 50-59$ years & & 1 & 2 & 1 & & & 1 \\
\hline $\mathrm{m} / 60-69$ years & & 2 & 3 & 1 & & & 2 \\
\hline f/60-69 years & & 2 & 3 & 2 & 1 & & 3 \\
\hline $\mathrm{m} / 70-79$ years & & 2 & 3 & 4 & 3 & & 3 \\
\hline f/70-79 years & & 3 & 5 & 6 & 4 & & 4 \\
\hline total & & & & & & & $14(56 \%)$ \\
\hline
\end{tabular}

Table 16: Evaluation of the effectiveness of the "Aganyan" patches according to the results of the MMSE test in patients with a diagnosis of depression.

\begin{tabular}{|c|c|c|c|c|c|c|c|c|}
\hline Gender/Age & $\begin{array}{c}\text { Number of patients } \\
\text { with 28-30 points } \\
\text { before after }\end{array}$ & $\begin{array}{c}\text { Number of patients } \\
\text { with 24-27 points } \\
\text { before / after }\end{array}$ & $\begin{array}{c}\text { Number of patients } \\
\text { with 20-23 points } \\
\text { before / after }\end{array}$ & $\begin{array}{c}\text { Number of patients } \\
\text { with 11-19 points } \\
\text { before / after }\end{array} \begin{array}{c}\text { Number of patients } \\
\text { with } \mathbf{0 - 1 0} \text { points } \\
\text { before / after the patch }\end{array}$ patients with positive \\
dynamics (\%)
\end{tabular}


In patients participating in the study, side effects were not registered, no exacerbation or worsening of the disease was found.

Results with "placebo patches" in patients participating in the study effects were not registered.

\section{Discussion}

Transcranial electrostimulation alternative treatment option for neuropsychiatric disorder.

Transcranial direct current stimulation (tDCS) is a noninvasive brain stimulation technique that passes an electrical current through the cortex of the brain in to alter brain function [12].

Transcranial electrostimulation modulates cortical excitability through the application of a weak direct current to the scalp via electrodes placed over cortical regions of interest [13-15].

The electrical current is applied to an individual's scalp usually via two or more electrodes, a portion of the current penetrates the scalp and is conducted through the brain, where it can alter neuronal excitability [16].

Since alterations in neural oscillations have been found in all major neurological conditions, it is vital that clinicians have a modulation technique for these potentially curative neurological conditions. The mechanism of action is that the applied electric current regulates the nerve cells in the brain $[17,18]$.

tDCS is induces glutamatergic plasticity via application of relatively weak currents through the scalp in humans [19].

In the last years its efficacy to treat neuropsychiatric diseases has been explored increasingly to ameliorate symptoms [20-23].

Knownand existingelectrostimulationtechniquesarebased on the use of wires or power supplies to generate electrical currents. Apparatus for transcranial electrostimulation uses 2 two electrodes anode and cathode [25].

These electrical stimulation devices are not only expensive but also inconvenient to use, especially when electrostimulation therapy has to be administered to the user for an extended period of time.

When exposed to the "Aganyan" patches, a low-intensity electric current is passed through the skin [26]. The indisputable advantages of this invention are the absence of side effects on the human body. The positive effect of this electrostimulation is achieved by the fact that not the same type of electrodes are used at the same time, but electrodes made of different metals, due to this, a potential difference is achieved. The uniqueness of this invention is that electrostimulation can work at large and small distances between the electrodes and can be used for long-term stimulation with low voltage and current without the use of wires and batteries.

According to the results of the Montreal test according to the criterion of memory and the MMSE test, the effectiveness of the patch was noted in patients with all clinical diagnoses. The greatest positive dynamics was revealed according to the results of the Montreal test according to the criterion of memory in patients with migraine (30\%), insomnia (31\%), vascular dementia $(32 \%)$, and according to the results of the MMSE test in patients with diagnoses: cerebrovascular disease: consequences of a cerebral infarction brain (31\%), vascular dementia (56\%).

After an analysis of brochures and a personal conversation, positive dynamics was found in $40 \%$ of patients with a diagnosis of migraine, in $56 \%$ of patients with a diagnosis of insomnia, and in $52 \%$ of patients with a diagnosis of depression.

This novel and affordable therapy can also be used in rehabilitation, preventive medicine, and other ailments with additional research.

\section{Conclusion}

The "Aganyan" patches has proven its effectiveness through electrical stimulation with low-intensity current in patients in different age groups with different clinical diagnoses.

\section{Acknowledgement}

Special acknowledgements "Aganyan INC", USA for providing the "Aganyan" patches and a special brochure, which describes in detail the method of using the patch.

Special Acknowledgments: Silvia Aganyan, Dr. Vagharshak Pilossyan, Dr. Leon Kiraj, Robert Avetisian, Hakop Aganyan, Dr. Aharon Baloyan, and Dr. Anait Khachatrian.

Ethical approval: Research protocol was approved by the local Ethical Committee (2018/23).

Informed consent: Written informed consent was obtained from all individual participants included in the study.

\section{References}

1. Thair H, Holloway AL, Newport R, Smith AD. Transcranial Direct Current Stimulation (tDCS): A Beginner's Guide for Design and Implementation. Front Neurosci. 2017; 11: 641.

PubMed: https://pubmed.ncbi.nlm.nih.gov/29213226/

2. Russowsky A, Nitsche MA, Bolognini N, Bikson M, Wagner T. Clinica Research with Transcranial Direct Current Stimulation (tDCS): Challenges and Future Directions. Brain Stimul J. 2012; 5: 175-195. PubMed: https://pubmed.ncbi.nlm.nih.gov/22037126/

3. Edwards D, Cortes M, Datta A, Minhas P, Wassermann EM, et al Physiological and modeling evidence for focal transcranial electrical brain stimulation in humans: a basis for high-definition tDCS. Neuroimage. 2013; 74: 266-275. 
PubMed: https://pubmed.ncbi.nlm.nih.gov/23370061/

4. Farahani F, Kronberg G, Rad MF, Oviedo HV, Par LC. Effects of direct current stimulation on synaptic plasticity in a single neuron. Brain Stimul. 2021; $14:$ 588-597.

PubMed: https://pubmed.ncbi.nlm.nih.gov/33766677/

5. Lu H, Gallinaro JV, Rotter S. Network remodeling induced by transcranial brain stimulation: A computational model of tDCS-triggered cell assembly formation. Netw Neurosci. 2019; 3: 924-943.

PubMed: https://pubmed.ncbi.nlm.nih.gov/31637332/

6. Brunoni AR, Moffa AH, Fregni F, Palm U, Padberg F, et al Transcrania direct current stimulation for acute major depressive episodes: Metaanalysis of individual patient data. Br J Psychiatry. 2016; 208: 522-531. PubMed: https://pubmed.ncbi.nlm.nih.gov/27056623/

7. Brunoni AR, Ferrucci R, Fregni F, Boggio PS, Priori A. Transcranial direct current stimulation for the treatment of major depressive disorder: a summary of preclinical, clinical and translational findings. Prog Neuropsychopharmacol Biol Psychiatry. 2012; 39: 9-16.

PubMed: https://pubmed.ncbi.nlm.nih.gov/22651961/

8. Stein DJ, Medeiros LF, Caumo W, Torres IL. Transcranial Direct Current Stimulation in Patients with Anxiety: Current Perspectives. Neuropsychiatr Dis Treat. 2020; 16: 161-169.

PubMed: https://pubmed.ncbi.nlm.nih.gov/32021208/

9. Tortella G, Casati R, Aparicio LVM, Mantovani A, Senço N, et al. Transcranial direct current stimulation in psychiatric disorders. World J Psychiatry. 2015; 5: 88-102.

PubMed: https://pubmed.ncbi.nlm.nih.gov/25815258/

10. Elsner B, Kugler J, Pohl M, Mehrholz J. Transcranial direct current stimulation (tDCS) for improving activities of daily living, and physical and cognitive functioning, in people after stroke. Cochrane Database Syst Rev. 2016; 3: CD009645.

PubMed: https://pubmed.ncbi.nIm.nih.gov/26996760/

11. Vásquez KA, Valverde EM, Aguilar DV, Gabarain HJH. Montreal Cognitive Assessment scale in patients with Parkinson Disease with normal scores in the Mini-Mental State Examination. Dement Neuropsychol. 2019; 13: 78-81.

PubMed: https://pubmed.ncbi.nlm.nih.gov/31073382/

12. Brunoni AR, Nitsche MA, Bolognini N, Bikson M, Wagner T, et al. Clinical research with transcranial direct current stimulation (tDCS):challenges and future directions. Brain Stimul. 2012; 5: 175-195.

PubMed: https://pubmed.ncbi.nlm.nih.gov/22037126/

13. Reed T, Kadosh RC. Transcranial electrical stimulation (tES) mechanisms and its effects on cortical excitability and connectivity $\mathrm{J}$ Inherit Metab Dis. 2018; 41: 1123-1130.

PubMed: https://pubmed.ncbi.nlm.nih.gov/30006770/

14. Kar K, Krekelberg B. Transcranial electrical stimulation over visual cortex evokes phosphenes with a retinal origin. J Neurophysiol. 2012; 108: 2173-2178.

PubMed: https://pubmed.ncbi.nlm.nih.gov/22855777/
15. Stagg CJ, Antal A, Nitsche MA. Physiology of transcranial direct current stimulation. J Ect. 2018; 34: 144-152.

PubMed: https://pubmed.ncbi.nlm.nih.gov/29877965/

16. Liu A, Vöröslakos M, Kronberg G, Henin S, Krause MR, et al. Immediate neurophysiological effects of transcranial electrical stimulation. Nat Commun. 2018; 9: 5092.

PubMed: https://pubmed.ncbi.nlm.nih.gov/30504921/

17. Buzsáki G, Watson BO. Brain rhythms and neural syntax: implications for efficient coding of cognitive content and neuropsychiatric disease. Dialogues Clin Neurosci. 2012; 14: 345-367.

PubMed: https://pubmed.ncbi.nlm.nih.gov/23393413/

18. Zich C, Harty S, Kranczioch C, Mansfield KL, Sella F, et al. Modulating hemispheric lateralization by brain stimulation yields gain in mental and physical activity. Sci Rep. 2017; 18: 13430.

PubMed: https://pubmed.ncbi.nlm.nih.gov/29044223/

19. Kuo MF, Paulus W, Nitsche MA. Therapeutic effects of non-invasive brain stimulation with direct currents (tDCS) in neuropsychiatric diseases. Neuroimage. 2014 15; 85: 948-960.

PubMed: https://pubmed.ncbi.nlm.nih.gov/23747962/

20. YIS,FoersterÁ, NitscheMA. Transcranialdirectcurrentstimulation(tDCS) - application in neuropsychology. Neuropsychologia. 2015; 69: 154-175. PubMed: https://pubmed.ncbi.nlm.nih.gov/25656568/

21. Giordano J, Bikson M, Kappenman ES, Clark VP, Coslett HB. Mechanisms and Effects of Transcranial Direct Current Stimulation. Dose Response. 2017; 15: 1559325816685467.

PubMed: https://pubmed.ncbi.nlm.nih.gov/28210202/

22. Moffaab AH, Martin D, Alonzo A, Bennabi D, Blumberger DM, et al. Efficacy and acceptability of transcranial direct current stimulation (tDCS) for major depressive disorder: An individual patient data meta-analysis. Prog Neuropsychopharmacol Biol Psychiatry. 2020; 99: 109836. PubMed: https://pubmed.ncbi.nlm.nih.gov/31837388/

23. Antala A, Alekseichuk I, Bikson M, Brockmöller J, Brunoni AR, et al. Low intensity transcranial electric stimulation: Safety, ethical, legal regulatory and application guidelines. Clin Neurophysiol. 2017; 128: 1774-1809. PubMed: https://pubmed.ncbi.nlm.nih.gov/28709880/

24. Sparingabc R, Mottaghyd FM. Noninvasive brain stimulation with transcranial magnetic or direct current stimulation (TMS/tDCS)-From insights into human memory to therapy of its dysfunction Methods. 2008; 44: 329-337.

PubMed: https://pubmed.ncbi.nlm.nih.gov/18374276/

25. Reinhart RMG, Cosman JD, Fukuda K, Woodman GF. Using transcranial direct-current stimulation (tDCS) to understand cognitive processing Atten Percept Psychophys. 2017; 79: 3-23. PubMed: https://pubmed.ncbi.nlm.nih.gov/27804033/

26. Hakobyan G, Khachikyan K, Shoman K, Ekaterina K, Lilit M. Evaluation of the clinical effectiveness of the method of Skin Rejuvenation using Electrostimulation. Int J Dermatol Skin Care. 2021; 3: 01-10. 